\title{
Phytochemical screening and antibacterial activity of Cola nitida seed on selected bacterial isolates
}

Dantani Dauda Odonye 1, ${ }^{*}$, Peter Uteh Upla ${ }^{1}$, Adegbe Lucy Ladi ${ }^{1}$, Enoch Peter Odonye ${ }^{2}$, Abisabo Adamu ${ }^{3}$, Peter Adikwu ${ }^{4}$, Mary lisaac Tsaku ${ }^{5}$, Usman Ibrahim Okposhi ${ }^{1}$, Naja'atu Shehu Hadi ${ }^{1}$ and Fatima Yusuf AlMustapha ${ }^{1}$

${ }^{1}$ Department of Microbiology, Federal University Lafia, Nigeria.

${ }^{2}$ Department of Microbiology, Federal University of Technology Owerri, Nigeria.

${ }^{3}$ National Biosafety Management Agency Abuja, Nigeria.

${ }^{4}$ Department of Microbiology, Benue state University, Marudi, Nigeria.

${ }^{5}$ Department of Biology, College of Education, Akwanga, Nigeria.

GSC Biological and Pharmaceutical Sciences, 2021, 14(03), 001-007

Publication history: Received on 15 January 2021; revised on 16 February 2021; accepted on 18 February 2021

Article DOI: https://doi.org/10.30574/gscbps.2021.14.3.0047

\begin{abstract}
Kola nut (Cola nitida) is chewed in many West African cultures and it is used ceremonially, industrially, medicinally and economically. The aim of this study was to assess the phytochemical properties and antibacterial activity of Cola nitida seeds. The seeds were purchased, dried and then powdered for phytochemical screening and extraction. Ethanol and aqueous (hot water) extracts were used for this study. The antibacterial activity of each extract at $30 \mathrm{mg} / \mathrm{ml}$ and 60 $\mathrm{mg} / \mathrm{ml}$ was tested on four bacterial isolates; Salmonella typhi, Staphylococcus aureus, Pseudomonas aeruginosa and Escherichia coli using the disc diffusion method on Mueller Hinton agar. The results revealed the presence of various potent phytochemicals such as alkaloids, polyphenols, tannins, flavonoids and glycosides. The zones of inhibition ranged from $0.0 \mathrm{~mm}$ to $28.0 \mathrm{~mm}$ for both concentrations of the ethanol extract and from $0.0 \mathrm{~mm}$ to $31.0 \mathrm{~mm}$ for both concentrations of the aqueous extract. The Minimum Inhibitory Concentration (MIC) ranged from $7.5 \mathrm{mg} / \mathrm{ml}$ to 30.0 $\mathrm{mg} / \mathrm{ml}$ for the ethanol extract and $3.75 \mathrm{mg} / \mathrm{ml}$ to $30.0 \mathrm{mg} / \mathrm{ml}$ for the aqueous extract. No minimum bactericidal concentration was recorded. Analysis of variance (ANOVA) performed on the data showed that there were significant differences in the zones of inhibition for each concentration of the extracts $(\mathrm{P}<0.05)$. The purified extract of Cola nitida seeds can be used to treat infections caused by these selected bacterial species.
\end{abstract}

Keywords: Cola nitida; Phytochemical; Antibacterial; Nigeria

\section{Introduction}

Cola nitida commonly called 'Goro' in Hausa, 'Oji' in Igbo, Obi-Abata in Yoruba and kola nut in English is a perennial crop that belongs to the family Steculacia. It grows up to $40 \mathrm{ft}$ high and is found in many areas of the world including Africa and Brazil [1]. Cola species occur in the hot tropical lowland forest which characterized by a period of about eight (8) months of rainfall with temperatures between 23 and $28{ }^{\circ} \mathrm{C}$. It can also be cultivated in the Savannah [2]. The nuts of a small number of Cola species including C. accuminata and C. nitida are edible, although some seeds are hard and inedible. Some Cola species are polycotyledonous. The seeds of the edible species are ovoid or ellipsoid with varying sizes of about $3 \mathrm{~cm}$ wide and $5 \mathrm{~cm}$ long. C. nitida is a dicotyledon [3].

\footnotetext{
* Corresponding author: Dantani Dauda Odonye

Department of Microbiology, Federal University Lafia, Nigeria.
} 
Infused $C$. nitida has been used to treat amenorrhoea, a physiological process that occurs in childhood, during pregnancy, during lactation and after menopause [4]. C. nitida has been used in folk medicine as an appetite suppressant, to treat headaches and indigestion and it can also be applied directly to the skin to treat boils and inflammation and also to clean the teeth and gums [5].

Cola. nitida is also used as a principal stimulant to keep awake by students and other menial workers, however, it contains a significant amount of caffeine and tannin and thus is not advised for individuals with stomach ulcers [6,7]. Plant derived substances are of great importance due to their versatile application. Medicinal plants are a rich source of drugs in traditional medicine, modern medicine and food supplements [8].

Due to an increase in world population, challenge in combating emerging and re-emerging infections still remains a problem. In countries of the sub-saharan Africa, many families survive under a dollar per day, resulting in malnutrition and unsensitized environments. The consequences of these are decreased resistance to diseases, retarded growth and in extreme cases, death [9]. Also, bacteria responsible for most illnesses like boils, urinary tract infections, tooth plague and so on tend to be resistant to most commercially synthesized antibiotics.

For many years, plants have been used as a valuable source of natural products for maintaining human health and a number of studies have shown that many plants during secondary metabolism produce active substances that have antimicrobial activity. An example is phenolic compounds which are part of essential oils [10].

The importance of this study is that it will reveal phytochemical substances and antibacterial activities possessed by $C$. nitida and to ascertain if regular intake and application is necessary. This study will show if the problem of antibiotic resistance can be combated, without adverse side effects and greatly reduce cost

\section{Material and methods}

\subsection{Collection of Plant Material}

The nuts of Cola nitida were purchased from Lafia Modern Market, Nasarawa State, North Central Nigeria. The seeds were further authenticated at the herbarium of the department of Botany, Federal University Lafia, Nasarawa State.

\subsection{Treatment of the Nuts}

The nuts were grated into small pieces, air-dried for two weeks at room temperature, grinded to powder and sieved. The powder obtained was stored in an air-tight container at $4^{\circ} \mathrm{C}$ prior to use.

\subsection{Phytochemical Profiling}

The phytochemical profiling of the nuts of Cola nitida was done according to the methods described by Raman and Houghton, 1998.

\subsection{Preparation of Ethanol and Aqueous Extracts}

The ethanol extract was prepared by using the method described by Durand et al., 2015. The method involved macerating $50 \mathrm{~g}$ of the Cola nitida powder in $500 \mathrm{~mL}$ of $96 \%$ ethanol for 72 hours. The substance obtained was filtered twice using the whatman filter paper. The filtrate was directly dried at $50^{\circ} \mathrm{C}$ in a water bath and the resulting extract was stored at $4^{\circ} \mathrm{C}$ in a refrigerator.

The aqeous extract was prepared using the method described by Jackie and Swamy, 2014. Fifty grams of the Cola nitida powder was mixed with $500 \mathrm{~mL}$ of sterile distilled water and heated to boiling for 20 minutes. The extract was filtered and the solvent was evaporated directly at $50^{\circ} \mathrm{C}$ in a water bath and the yield was kept at $4^{\circ} \mathrm{C}$ prior to use.

\subsection{Collection of Bacterial Isolates}

Pure isolates of Staphylococcus aureus, Salmonella typhi, Escherichia coli and Pseudomonas aeruginosa were collected from National Veterinary Research Institute (N.V.R.I) Vom, Plateau State. The organisms were further subjected to biochemical test for their confirmation, maintained on slants and stored at $4^{\circ} \mathrm{C}$ in a refrigerator prior to usage. 


\subsection{Bioassay Study}

\subsubsection{Preparation of media}

Mueller Hinton agar and broth were used for the study and were prepared according to the manufacturer's instruction.

\subsubsection{Preparation of bacterial suspension}

The turbidity of each bacterial suspension was prepared to match a 0.5 McFarland standard. The 0.5 McFarland standard was prepared by mixing $0.5 \mathrm{ml}$ of $1 \%$ Barium Chloride (w/v) with $99.5 \mathrm{ml}$ of 1\% sulphuric acid (w/v). The turbidity of the $0.5 \mathrm{McF}$ arland standard was measured with the aid of spectrophotometer at a wavelength of $625 \mathrm{~nm}$ to read an optical density between 0.08 and 1.0. At this absorbance, the McFarland standard represents a bacterial cell density of approximately $1.5 \times 10^{8} \mathrm{CFU} / \mathrm{mL}$. The bacterial suspension was then tested against the McFarland standard until they reached the absorbance of the McFarland standard and then they were ready for use.

\subsubsection{Preparation of extract stock solution}

The extract was dissolved in distilled water and made up to concentrations of $30 \mathrm{mg} / \mathrm{ml}$ and $60 \mathrm{mg} / \mathrm{ml} \mathrm{respectively}$

\subsubsection{Preparation of Cola nitida extract disc}

The disc diffusion method was used to screen for antibacterial activity. Paper disc of $6 \mathrm{~mm}$ diameter were made, sterilized and aseptically spread out in two Petri dishes (one for the $30 \mathrm{mg} / \mathrm{ml}$ and the other for the $60 \mathrm{mg} / \mathrm{ml}$ concentration of the extract respectively) and $0.1 \mathrm{ml}$ of the Cola nitida extracts were aseptically impregnated unto each disc for both concentrations. This was left for 48 hours for proper absorption. The antibiotic ciprofloxacin was used as positive control while blank disc impregnated with water was used as negative control.

\subsubsection{Antibacterial activity}

Paper disc impregnated with $30 \mathrm{mg} / \mathrm{ml}$ and $60 \mathrm{mg} / \mathrm{ml}$ stock solutions were aseptically lodged on Mueller Hinton agar plates previously streaked with the appropriate bacterial isolate. The dishes were kept at room temperature for 15-30 minutes for proper adherence of the impregnated disc to the surface of the agar before incubating at $37^{\circ} \mathrm{C}$ for 24 and 48 hours respectively. After incubation, the dishes were examined for zones of inhibition.

\subsubsection{Determination of minimum inhibitory concentration}

The minimum inhibitory concentration of the crude extract was performed by the macrodilution method described by Saha and Ramah, 2008. First the extracts were diluted in sterile distilled water to a highest concentration of $60 \mathrm{mg} / \mathrm{ml}$ and then nine dilutions were performed to obtain concentrations of $30 \mathrm{mg} / \mathrm{ml}, 15 \mathrm{mg} / \mathrm{ml}, 7.5 \mathrm{mg} / \mathrm{ml}, 3.75 \mathrm{mg} / \mathrm{ml}, 1.875$ $\mathrm{mg} / \mathrm{ml}, 0.9375 \mathrm{mg} / \mathrm{ml}, 0.463 \mathrm{mg} / \mathrm{ml}, 0.234 \mathrm{mg} / \mathrm{ml}$ and $0.117 \mathrm{mg} / \mathrm{ml}$ in a capped tube. To $1 \mathrm{ml}$ of the above concentrations, was added $1 \mathrm{ml}$ of bacterial inoculum to obtain $2 \mathrm{ml}$ as final volume. The first tube containing $60 \mathrm{mg} / \mathrm{ml}$ of the extract, neither broth nor inoculum was added and this served as positive control. A separate tube containing broth and inoculum alone served as negative control. The tubes were then incubated at $37{ }^{\circ} \mathrm{C}$ for 18 hours and growth was indicated by turbidity. The Minimum inhibitory concentration is the lowest concentration at the microorganism tested shows no visible growth (turbidity).

\subsubsection{Minimum bactericidal concentration}

The minimum bactericidal concentration was done using the method described by Durand et al., 2015. This was determined by subculturing the test dilution onto a fresh solid medium and further incubated at 18-24 hours. The highest dilution that yielded no bacterial growth on the solid medium was taken as the minimum bactericidal concentration.

\subsubsection{Statistical Analysis}

The data obtained from the research was subjected to the one-way analysis of variance using the SPSS software. The zones of inhibition for each extract at the same concentration were compared to see if there were significant differences between them

\section{Results}

The results of the phytochemical screening of Cola nitida seeds revealed the presence of various phytochemicals. This is shown in the table 1 below. 
Table 1 Phytochemicals Present in the Seeds of Cola nitida

\begin{tabular}{|l|c|}
\hline Phytochemicals & Cola nitida seed \\
\hline Alkaloids & + \\
\hline Saponins & + \\
\hline Tanins & + \\
\hline Flavonoids & + \\
\hline Glycosides & + \\
\hline Reducing compounds & + \\
\hline Polyphenols & + \\
\hline
\end{tabular}

\subsection{Antibacterial Activity}

Tables 2 and 3 shows results for various antibacterial activity of ethanol and aqueous extracts of Cola nitida seeds both at $30 \mathrm{mg} / \mathrm{ml}$ and $60 \mathrm{mg} / \mathrm{ml}$. The ethanol extract at $60 \mathrm{mg} / \mathrm{ml}$ showed higher zones of inhibition both at 24 and 48 hours than at $30 \mathrm{mg} / \mathrm{ml}$. At $30 \mathrm{mgml}$, Pseudomonas aeruginosa showed no zone of inhibition, while at $60 \mathrm{mg} / \mathrm{ml}$ a zone of $18 \mathrm{~mm}$ was recorded. At 24 hours, the zones of inhibition recorded for Salmonella typhi was 22mm and 26mm, Staphylococcus aureus was $8 \mathrm{~mm}$ and $24 \mathrm{~mm}$, Pseudomonas aeruginosa was $0 \mathrm{~mm}$ and $18 \mathrm{~mm}$ and that of Escherichia coli was $8 \mathrm{~mm}$ and $24 \mathrm{~mm}$, both at $30 \mathrm{mg} / \mathrm{ml}$ and $60 \mathrm{mg} / \mathrm{ml}$ respectively. At 48 hours, the zones of inhibition for $S$. typhi increased to 23 and $28 \mathrm{mg} / \mathrm{ml}$ at $30 \mathrm{mg} / \mathrm{ml}$ and $60 \mathrm{mg} / \mathrm{ml}$ respectively, while that of E. coli decreased from $8 \mathrm{~mm}$ to $7 \mathrm{~mm}$ at $30 \mathrm{mg} / \mathrm{ml}$. All other zones of inhibition remained the same both at 24 and 48 hours.

The aqeous extract showed zones of inhibition both at $30 \mathrm{mg} / \mathrm{ml}$ and $60 \mathrm{mg} / \mathrm{ml}$ respectively. At $60 \mathrm{mg} / \mathrm{ml}$, E. coli showed no zone of inhibition, while at $30 \mathrm{mg} / \mathrm{ml}$ a zone of inhibition occurred. S. typhi showed a zone of inhibition of $14 \mathrm{~mm}$ and $16 \mathrm{~mm}, S$. aureus showed $10 \mathrm{~mm}$ and $9 \mathrm{~mm}$, P. aeruginosa $28 \mathrm{~mm}$ and $29 \mathrm{~mm}$ and E. coli showed $11 \mathrm{~mm}$ and $0 \mathrm{~mm}$ at $30 \mathrm{mg} / \mathrm{ml}$ and $60 \mathrm{mg} / \mathrm{ml}$ respectively. At 48 hours, the zones of inhibition for $S$. typhi increased to 16 and $28 \mathrm{~mm}$ at $30 \mathrm{mg} / \mathrm{ml}$ and $60 \mathrm{mg} / \mathrm{ml}$ respectively. At $60 \mathrm{mg} / \mathrm{ml}$, the zone of inhibition for P. aeruginosa increased from 29 to $31 \mathrm{~mm}$. All other zones of inhibition remained the same both at 24 and 48 hours.

Table 2 Zones of inhibition of ethanol and aqueous extracts at 24 hours of growth

\begin{tabular}{|l|l|l|l|l|}
\hline Selected Bacteria & \multicolumn{4}{|l|}{ Zones of Inhibition (mm) } \\
\hline & ET 30 & ET 60 & AQ 30 & AQ 60 \\
\hline Salmonella typhi & 22.0 & 26.0 & 14.0 & 25.0 \\
\hline Staphylococcus aureus & 8.0 & 24.0 & 10.0 & 9.0 \\
\hline Pseudomonas aeruginosa & 0.0 & 18.0 & 28.0 & 29.0 \\
\hline Escherichia coli & 8.0 & 24.0 & 11.0 & 0.0 \\
\hline
\end{tabular}

Keys: ET30- Ethanol extract at 30mg/ml, ET 60- Ethanol extract at $60 \mathrm{mg} / \mathrm{ml}, \mathrm{AQ} 30$-Aqueous extract at 30mg/ml, AQ 60-Aqueous extract at $60 \mathrm{mg} / \mathrm{ml}$

Table 3 Zones of inhibition of ethanol and aqueous extracts at 24 hours of growth

\begin{tabular}{|l|l|l|l|l|}
\hline \multirow{2}{*}{ Selected Bacteria } & \multicolumn{4}{|l|}{ Zones of Inhibition (mm) } \\
\cline { 2 - 5 } & ET 30 & ET 60 & AQ 30 & AQ 60 \\
\hline Salmonella typhi & 22 & 26 & 14 & 25 \\
\hline Staphylococcus aureus & 8 & 24 & 28 & 29 \\
\hline Pseudomonas aeruginosa & 0 & 18 & 10 & 9 \\
\hline Escherichia coli & 8 & 24 & 11 & 0 \\
\hline
\end{tabular}


Table 4 Zones of inhibition of ethanol and aqueous extracts at 48 hours of growth.

Zones of Inhibition (mm)
\begin{tabular}{|l|l|l|l|l|}
\hline Selected Bacteria & ET 30 & ET 60 & AQ 30 & AQ 60 \\
\hline Salmonella typhi & 23.0 & 28.0 & 16.0 & 28.0 \\
\hline Staphylococcus aureus & 8.0 & 24.0 & 10.0 & 9.0 \\
\hline Pseudomonas aeruginosa & 0.0 & 18.0 & 28.0 & 31.0 \\
\hline Escherichia coli & 7.0 & 24.0 & 11.0 & 0.0 \\
\hline
\end{tabular}
Keys: ET30- Ethanol extract at 30mg/ml, ET 60- Ethanol extract at 60mg/ml, AQ 30-Aqueous extract at 30mg/ml, AQ 60-Aqueous extract at
60

\subsection{Minimum Inhibitory Concentration}

The minimum inhibitory concentration values presented in table 5 shows the lowest concentrations at which the ethanol and aqueous extracts of Cola nitida exhibited bacteriostatic activity. The minimum inhibitory concentration of the ethanol extract for $S$. typhi was $7.5 \mathrm{mg} / \mathrm{ml}$, for $S$. aureus $30 \mathrm{mg} / \mathrm{ml}$, for $E$. coli $30 \mathrm{mg} / \mathrm{ml}$ and there was no minimum inhibitory concentration for $P$. aeruginosa. The minimum inhibitory concentration of the aqueous extract for $S$. typhi was $15 \mathrm{mg} / \mathrm{ml}$, for $S$. aureus was $30 \mathrm{mg} / \mathrm{ml}$, for E. coli was $30 \mathrm{mg} / \mathrm{ml}$ while that of P. aeruginosa was $3.75 \mathrm{mg} / \mathrm{ml}$.

\subsection{Minimum Bactericidal Concentration}

There was no minimum bactericidal concentration for each concentration of the ethanol and aqueous extracts.

The values for the zones of inhibition at $30 \mathrm{mg} / \mathrm{ml}$ for both the ethanol and aqueous extract showed that a significant difference existed for $E$. coli, $P$. aeruginosa and $S$. typhi, while no significant difference existed for $S$. aureus. The percentage activity for the ethanol extract was $25 \%$ and the aqueous extract was $75 \%$. At $60 \mathrm{mg} / \mathrm{ml}$, a significant difference occurred for $S$. aureus, P. aeruginosa and E. coli, while no significant difference occurred for $S$. typhi. Here, the percentage activity for both extracts was $50 \%$ each.

Table 5 Minimum Inhibitory Concentration for the ethanol and aqueous extracts

\begin{tabular}{|l|l|l|}
\hline & \multicolumn{2}{|l|}{$\begin{array}{l}\text { Minimum Inhibitory Concentration } \\
\text { (mg/ml) }\end{array}$} \\
\hline Selected bacteria & Ethanol extract & Aqueous extract \\
\hline Salmonella typhi & 7.5 & 15 \\
\hline Staphylococcus aureus & 30 & 30 \\
\hline Pseudomonas aeruginosa & - & 3.75 \\
\hline Escherichia coli & 30 & 30 \\
\hline
\end{tabular}

Table 6 Zones of Inhibition recorded for Ciprofloxacin Antibiotic

\begin{tabular}{|l|c|}
\hline Selected Bacteria & Zone of Inhibition (mm) \\
\hline Salmonella typhi & 30.0 \\
\hline Staphylococcus aureus & 27.0 \\
\hline Pseudomonas aeruginosa & 26.0 \\
\hline Escherichia coli & 24.0 \\
\hline
\end{tabular}




\section{Discussion}

The qualitative screening of Cola nitida seed extracts revealed the presence of various phytochemical components such as tannins, flavonoids, and saponins (Table 1). The presence of tannins in the tested extract suggests the probable biological activities. Indeed, tannins are reported not only to promote tissue regeneration in case of superficial burn injury but also to have antibacterial, antiviral, antifungal, and antioxidant effects [11].

Analysing tables 2 and 3, it appears that the inhibition diameters were slightly significantly different depending on the extract solvent with regards to the duration (24 hrs and $48 \mathrm{hrs}$ ) on both $S$. typhi and P. aeruginosa. The results are different from those of [12].in their study when they observed a significant difference of inhibition diameters in the time. [12], used 10 times less concentration to that used for this study; that may thus be one of the reasons. Indeed, with the highest concentration, it is possible to have an increase of the inhibition diameter because the active antibacterial substance is in excess.

Concerning the bacteria when the concentration of both extracts used was at $30 \mathrm{mg} / \mathrm{ml}$, the results indicate that the solvent plays a role in the extraction of active principles (Table 2 and 3). The ethanol extracts were less effective than the aqueous extracts $(\mathrm{P}<0.05)$ on the bacterial isolates used. These results are similar to those [13], obtained during their study on Terminalia glaucescens when they demonstrated that the aqueous extract was more effective than the ethanol extract at the same dose on certain microorganisms. The possible explanation to the difference of activity between the two extracts may be the ability of solvent to solubilize and extract some phytomolecules. Thus, according to [14], during the liquid-liquid extraction, phytomolecules are distributed between the solvents according to their polarity and solubility. It can be thus concluded that the active antibacterial compounds contained in the nuts of $C$. nitida are more soluble in the aqueous solvent than ethanol.

The minimum inhibitory concentration showed variability in the results depending on the extract type and concentration. It also showed that the aqueous extract was more efficient in inhibiting the growth of $P$. aeruginosa (at $3.75 \mathrm{mg} / \mathrm{ml}$ ) compared to other bacterial isolates used in the study. The concentrations were higher than those reported by [15], when they proved that $S$. aureus strains were more sensitive to the ethanol leaf extract of Anacardium occidentale with MIC $=15.62 \mathrm{ug} / \mathrm{ml}$. The difference may probably be due to the divergent extraction methods and the different origins of strains used. Indeed, depending on the extraction methods, the antibacterial agents extracted may have different concentrations. Also, this indicates that $C$. nitida's nuts extracts were less active at lowest concentration compared with those of $A$. occidentale.

There was no positive result for the minimum bactericidal concentration. This is contrary to the works of [16]. They reported an MBC range of 0.078 to $1.25 \mathrm{mg} / \mathrm{mL}$ for meat isolated Staphylococcus strains using Cola nitida bark extract. The difference may be due to the variations in the phytochemical composition of the extracts of the various plant organs (bark and seed) as well as the origin of the strains. The Staphylococci strain used in this study were clinical isolates.

According to [17], methanol and water-soluble fractions of Garcinia kola and Cola nitida possess antibacterial activity, G. kola was more active against some members of Enterobacteriaceae, namely, Escherichia coli and Salmonella typhi, whereas, methanol extracts of Cola nitida showed greater activity on $S$. aureus. This is in contrast to this study. The difference may be because the antibacterial substances that are effective against $S$. aureus may be more soluble in methanol compared to water and ethanol.

Thus, the plants possess potentials for the manufacture of potent drugs for the treatment of infections caused by the test organisms, such as typhoid fever, gastroenteritis, urogenital tract infections and boils.

In Nigeria, various concoctions are made from roots, seeds and leaves obtained from a variety of the kola tree. And they are administered orally as purgatives, as direct cures or preventions of all sorts of diseases.

\section{Conclusion}

From the obtained results, it can be said that Cola nitida seed contains many secondary metabolites dominated by polyphenol compounds. The presence of those compounds confers to $C$. nitida seed, through the ethanol and the aqueous extract, some important biological activities. The tested extract displayed more bactericidal activity against $P$. aeruginosa. Furthermore, of the investigated biological activity, the aqueous extract is more effective than the ethanol extract. The more purified extracts of $C$. nitida seed can be useful in human medicine 


\section{Compliance with ethical standards}

\section{Acknowledgments}

We sincerely acknowledged the contributions from the Laboratory Staff of Microbiology Department, Federal University of Lafia for their assistance in the laboratory analyses of the samples.

\section{Disclosure of conflict of interest}

The authors whose names are mentioned hereby declare that they have no conflict of interest in this research article and that in case any of such comes up, it will be resolved hitch-free. The authors also declare that this research is solely sponsored by them without any external intervention.

\section{References}

[1] Asogwa EU, Otuonye AH, Mokwunye FC, Oluloye KA, Ndubuakku TCN, Uwagboe EU. Kola nut Production, Processing and Marketing in the South-Eastern States of Nigeria. African Journal of Plant Science. 2011; 5(10): 477-551.

[2] Ogutuga DBA. Chemical Composition and Potential Commercial Uses of Cola nitida. Ghana Journal of Agricultural Science. 2005; 8: 121-125.

[3] Keay RJW, Onochie CFA, Stanfield DP. Nigerian Trees. Journal Forest Research. 1964; 1: 51-54.

[4] Jackie KO, Swamy IA. In vitro Evaluation of Antimicrobial Activity of Infused Cola nitida seeds. International Journal of Current Microbiology and Applied Sciences. 2014; 36: 11-41.

[5] Esimone CO, Adikwu MU, Nworu CS, Okoye FBC, Odimegwu DC. Adaptogenic Potentials of Camellia sinensis leaves, Garcinia kola and C. nitida seeds. Science Research Essay. 2007; 2(7): 232-237.

[6] Chukwu LU, Odiete WO, Briggs LS. Basal Metabolic Responses and Rhythmic Activity of the Mammalian Heart to Aqueous Kola nut Extract. African Journal of Biotechnology. 2006; 5(5): 484-486.

[7] Newall C, Anderson LA, Philipson JD. Herbal Medicines: a guide Health Care Professionals. England: Pharmaceutical Press. 1996; 84.

[8] Ncube NS, Afolayan AJ, Okoh AI. Assessment Techniques of Antimicrobial Properties of Natural Components of Plant Origin: Current Methods and Future Trends. African Journal of Biotechnology. 2008; 7(12): 1797-1806.

[9] Scellern C. Rogers P. Nutrition and Basic Botany. Newyork: Academic Press. 1979; 100-105.

[10] Obey JK, Swamy TK. In vitro Evaluation of Antibacterial Activity of Infused Cola nitida seeds. International Journal of Current Microbiology and Applied Sciences. 2004; 3(10): 11-22.

[11] Saha A, Rahma MS. Antimicrobial Activity of Crude Extract of Calycopteris florobunsa. Bangledesh Journal of Microbiology. 2008; 25(2): 137-139.

[12] Agbeniyi SO, Otuoye AH, Adedeji AR. Mycoflora Associated with Post-Harvest Processing Stages of Kola nut. The Journal of Food Technology in Africa. 2000; 5(4): 129-131.

[13] Bolou GEK, Attioua B, N'Guessan AC, Coulibaly AJ, N'Guessan D, Djaman AJ. Evaluation in vitro de l'activit'e antibact'erienne des extraits de Terminalia glaucescens planch.sur Salmonella typhi et Salmonella typhimurium, Bulletin de laSoci'et'e Royale des Sciences de Li'ege. 2011; 80: 772-790.

[14] Cowan MM. Plant products as antimicrobial agents," Clinical Microbiology Reviews. 1999; 12(4): 564-582.

[15] Dahake AP, Joshi VD, Joshi AB. Antimicrobial screening of different extracts of Anacardium occidentale leaves," International Journal of Chemical Technology Research. 2009; 1(4): 856-858.

[16] Durand D, Hubert A, Nafan D, Haziz S, Adolphe A, Inoussa M, Donald A, Joachim DG, Simeon OK, Mamoudou HD, Lemine B. Phytochemical Analysis and Biological Activities of Cola nitida Bark. Biochemistry Research International. 2015; 10: 22-34.

[17] Indabawa I, Arzai M. Antibacterial activity of the methanolic extract of G. cola and $C$. nitida on some bacteria. Bayero Journal of Microbiology. 2011; 6(1): 1-5. 